\title{
Normas para Publicação
}

Os textos encaminhados e submetidos à apreciação e à aprovação do Conselho Editorial da Revista Atualidade Teológica são de total responsabilidade dos seus autores e de suas autoras, e deverão respeitar as seguintes normas: de 10 a 12 páginas para artigos, de 6 a 8 páginas para comunicações e de 2 a 5 páginas para resenhas.

Deve-se utilizar a letra Times New Roman, caractere 11 para o corpo do texto e caractere 9 para as notas de rodapé no modelo $A 4$, com as seguintes margens: $2,5 \mathrm{~cm}$ superior; $2,5 \mathrm{~cm}$ inferior; $2,5 \mathrm{~cm}$ direita; $2,5 \mathrm{~cm}$ esquerda. $O$ espaçamento entre as linhas é simples, com $0 \mathrm{~cm}$ para o antes e o depois de cada parágrafo, que terá $\mathbf{1} \mathbf{c m}$ adentrado na primeira linha.

O título geral e subtítulo do artigo, comunicação ou resenha, ficarão alinhados à direita, utilizando-se a fonte Times New Roman negrito, caractere 18 para o título e 15 para o subtítulo.

O nome do autor do artigo, comunicação ou resenha, aparecerá duas vezes:

$1^{\circ}$ ) no início do texto, abaixo do título geral, alinhado à direita, fonte Times New Roman itálico e caractere 12;

$2^{\circ}$ ) no final do texto, alinhado à direita, fonte Times New Roman itáliconegrito e caractere 12 . 
Estrutura geral do texto a ser seguida: Título, Nome do Autor, Resumo contendo entre 150 e 200 palavras em Português, bem como Palavras-chave (4 no máximo). Resumo e Palavras-chave também em uma segunda língua (Alemão, Espanhol, Francês, Inglês, Italiano); Introdução, Corpo do texto (com as suas diversas partes), Conclusão, Referências Bibliográficas e breves dados, 4 linhas no máximo, sobre o autor ou autora: sua maior titulação, filiação institucional e e-mail para contato.

As normas da ABNT (norma NBR 6023) serão seguidas nas indicações bibliográficas citadas nas notas de rodapé e na bibliográfica final. A primeira citação de cada obra, na nota de rodapé, deverá ser sempre completa, contendo as seguintes informações: autor, título da obra (volume se houver), edição, local da publicação, editora e ano da publicação. Alguns exemplos básicos de referências bibliográficas:

\section{Livro:}

GOMES, C. F., Riquezas da Mensagem Cristã. Rio de Janeiro: Lumen Christi 1983.

\section{Parte de livro:}

FANULI,A., “As ‘Tradições' nos Livros Históricos do AT. Novas Orientações”. In: R. Fabris (org), Problemas e Perspectivas das Ciências Bíblicas. São Paulo: Loyola, 1933, pp. 11-35.

\section{Artigo de periódico:}

COSTA, P. C., "Diálogo entre Cristianismo e mundo cultural nos primeiros séculos", Atualidade Teológica 33 (2009) pp. 313-331.

\section{Verbete de dicionário:}

COURT, J. M., "Millenarianism”. In: R. J. Coggins - J. L. Houlden (ed.), A Dictionary of Biblical Interpretation. SCM Press, London, 1990, pp. 459-461.

\section{Artigo de jornal:}

BERTONE, T. O Pai-Nosso dever ressoar na vida do cristão. L'Osservatore Romano, Roma, p. 1, 31 de julho de 2010.

\section{Citação eletrônica:}

BERTONE, T. O Pai-Nosso dever ressoar na vida do cristão. L'Osservatore Romano, Roma, 31 de julho de 2010. Disponível em: $<$ http://www. vatican.va/news_services/or/or_por/text.html\#1>. Acesso em 04 de agosto de 2010 . 
Conteúdo, correção linguístico-ortográfica, forma e estilo dos textos submetidos são de total e inteira responsabilidade dos seus autores e de suas autoras, ficando a revista isenta de quaisquer encargos ou ônus a esse respeito.

Encaminhe o artigo, a comunicação ou a resenha para o e-mail do editora: atualidadeteologica@puc-rio.br, fornecendo, inclusive, um número de telefone para contato e o endereço completo. Os autores e as autoras serão notificados quanto à aprovação ou não do texto submetido. Sendo aprovado, os direitos autorais são cedidos à Atualidade Teológica e, igualmente, fica autorizada a publicação do artigo, da comunicação ou da resenha em formato impresso e digital. Pelos direitos autorais cedidos, os autores e autoras receberão três exemplares pelo artigo e dois exemplares pela comunicação ou resenha. 